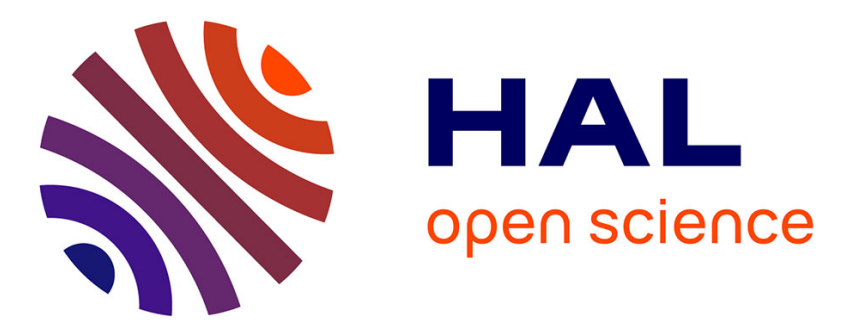

\title{
Adsorption onto ACFC of mixture of pharmaceutical residues in water - experimental studies and modelling
}

Hélène Fallou, Sylvain Giraudet, Nicolas Cimetiere, Dominique Wolbert, Pierre Le Cloirec

\section{- To cite this version:}

Hélène Fallou, Sylvain Giraudet, Nicolas Cimetiere, Dominique Wolbert, Pierre Le Cloirec. Adsorption onto ACFC of mixture of pharmaceutical residues in water - experimental studies and modelling. Environmental Technology, 2021, pp.1-11. 10.1080/09593330.2020.1716393 . hal-02498323

HAL Id: hal-02498323

https://hal-univ-rennes1.archives-ouvertes.fr/hal-02498323

Submitted on 31 Mar 2020

HAL is a multi-disciplinary open access archive for the deposit and dissemination of scientific research documents, whether they are published or not. The documents may come from teaching and research institutions in France or abroad, or from public or private research centers.
L'archive ouverte pluridisciplinaire HAL, est destinée au dépôt et à la diffusion de documents scientifiques de niveau recherche, publiés ou non, émanant des établissements d'enseignement et de recherche français ou étrangers, des laboratoires publics ou privés. 
Publisher: Taylor \& Francis \& Informa UK Limited, trading as Taylor \& Francis Group

Journal: Environmental Technology

DOI: $10.1080 / 09593330.2020 .1716393$

\title{
Adsorption onto ACFC of mixture of pharmaceutical residues in water - Experimental studies and modelling
}

Hélène Fallou, Sylvain Giraudet, Nicolas Cimetière, Dominique Wolbert, Pierre Le Cloirec*

Univ Rennes, Ecole Nationale Supérieure de Chimie de Rennes, CNRS, UMR 6226, 11 allée de Beaulieu, CS 50837, 35708 Rennes Cedex 7, France

* Corresponding author: Pierre.le-Cloirec@ensc-rennes.fr; Tel. $(+33)(0) 223238065$

\begin{abstract}
The presence of pharmaceutical residues in water resources is a critical issue for the production of drinking water, even though trace concentrations are mostly encountered. The adsorption of eight micropollutants, in mixture, onto a microporous activated carbon fiber cloth was investigated. For each compound, the kinetics and isotherms of adsorption were studied in batch reactors with ultrapure water, groundwater and half-diluted groundwater. Experimental data were generated and compared to values calculated by the association of Ideal Adsorbed Solution Theory (IAST) model and the Homogeneous Surface Diffusion Model (HSDM). The impact of the nature and the content of Natural Organic Matter (NOM) was modeled considering an Equivalent Background Compound (EBC). The presence of NOM in the groundwater is largely detrimental for the adsorption of trace micropollutants.
\end{abstract}


Adsorption of pharmaceutical residues on activated carbon fiber cloths

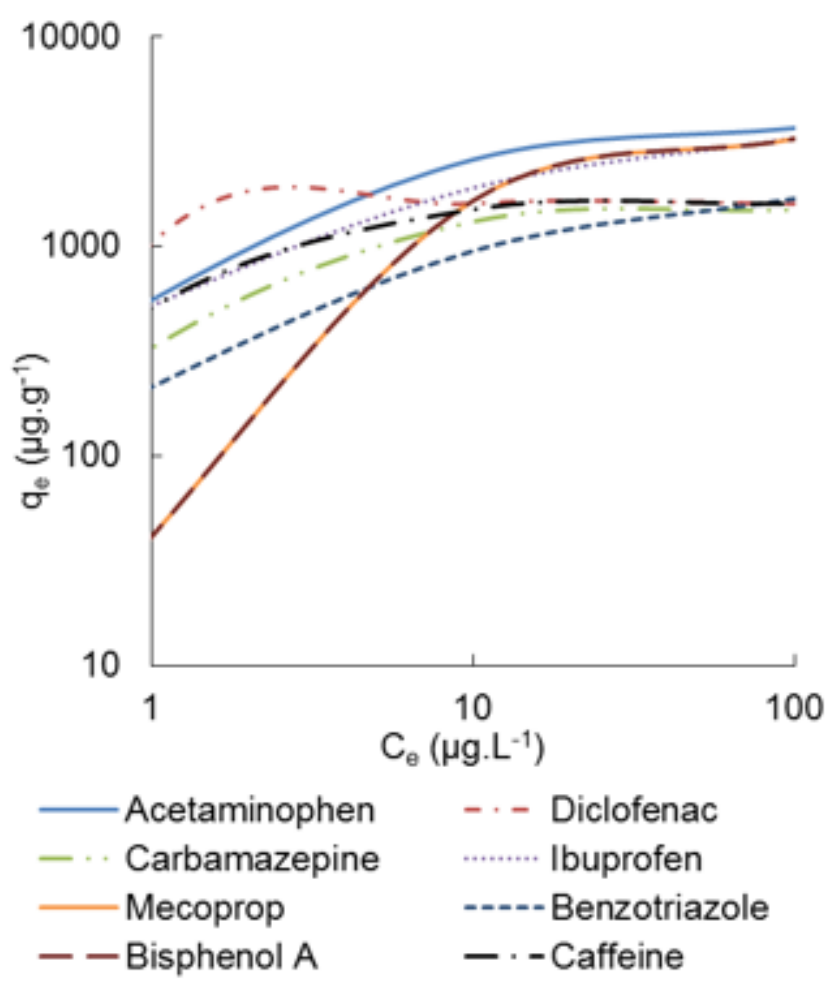

\section{Equivalent Background Compound versus micropollutants}

Keywords: Adsorption; activated carbon fiber cloth; natural organic matter; pharmaceutical residues; modelling 


\section{List of symbols}

A Interfacial surface area $\left(\mathrm{L}^{2} \mathrm{~L}^{-3}\right)$

b Parameter of the Langmuir - Freundlich equation $\left(\mathrm{L}^{3 / n} \mathrm{M}^{-1 / n}\right)$

Bi Biot number (-)

$\mathrm{C}_{\mathrm{i}} \quad$ Concentration of the component (i) in the multicomponent solution $\left(\mathrm{ML}^{-3}\right)$

$\mathrm{C}^{\circ}{ }_{\mathrm{i}} \quad$ Concentration of the component (i) in the monocomponent solution $\left(\mathrm{ML}^{-3}\right)$

$\mathrm{C}_{\mathrm{ei}} \quad$ Concentration of the component (i) in the multicomponent solution at the equilibrium $\left(\mathrm{ML}^{-3}\right)$

$\mathrm{C}_{0} \quad$ Initial concentration $\left(\mathrm{ML}^{-3}\right)$

$\mathrm{D}_{\mathrm{s}} \quad$ Surface diffusion coefficient $\left(\mathrm{L}^{2} \mathrm{~T}^{-1}\right)$

$d_{p} \quad$ Diameter of the particle (L)

$\mathrm{k}_{\mathrm{f}} \quad$ External mass transfer coefficient $\left(\mathrm{LT}^{-1}\right)$

m Mass of adsorbent $(M)$

$\mathrm{n} \quad$ Parameter of the Langmuir - Freundlich equation $(-)$

$\mathrm{n}_{\mathrm{c}} \quad$ Number of components in the solution

$\mathrm{q}_{\mathrm{ei}} \quad$ Concentration of the component (i) in solid phase in multicomponent adsorption at equilibrium $\left(\mathrm{MM}^{-1}\right)$

$\mathrm{q}_{\mathrm{ei}, \mathrm{mod}}$ Simulated concentration of the component (i) in solid phase in multicomponent adsorption at equilibrium $\left(\mathrm{MM}^{-1}\right)$

$\mathrm{q}_{\mathrm{ei}, \text { exp }}$ Experimental concentration of the component (i) in solid phase in multicomponent adsorption at equilibrium $\left(\mathrm{MM}^{-1}\right)$

$\mathrm{q}_{\mathrm{i}} \quad$ Concentration of the component (i) in solid phase in multicomponent adsorption $\left(\mathrm{MM}^{-1}\right)$

$\mathrm{q}^{\circ} \quad$ Concentration of the component (i) in solid phase in monocomponent adsorption $\left(\mathrm{MM}^{-1}\right)$

$\mathrm{q}_{\mathrm{m}}$ Maximum adsorption capacity of the component (i) $\left(\mathrm{MM}^{-1}\right)$

qT Total concentration in the solid phase $\left(\mathrm{MM}^{-1}\right)$

R Ideal gas constant $\left(\mathrm{LT}^{-2} \square^{-1}\right)$

$r_{p} \quad$ Radius of fiber (L)

T $\quad$ Temperature ( $\square$ )

t Time (T)

V Volume of the solution $\left(\mathrm{L}^{3}\right)$ 
$\mathrm{Z}_{\mathrm{i}} \quad$ Molar fraction in adsorbed phase

$\square \mathrm{m} \quad$ Spreading pressure in the multicomponent system $\left(\mathrm{MT}^{-2}\right)$

Spreading pressure of the component (i) in the monocomponent system $\left(\mathrm{MT}^{-2}\right)$

Apparent density of particle $\left(\mathrm{ML}^{-3}\right)$

\section{Introduction}

The contamination of aquatic systems by pharmaceutical residues is now a major concern for the environment and risk assessments are necessary for human health [1][2][3][4]. All aquatic compartments are impacted. In European rivers, Loos et al. [5] have detected diclofenac in $83 \%$ of their samples. The maximum concentration was found to be 11 ng. $\mathrm{L}^{-1}$ for de Jesus Gaffney [1]. Likewise, carbamazepine and acetaminophen were identified and quantified at concentrations of 200 ng. $\mathrm{L}^{-1}$ in surface waters [6]. More recently, Bazus et al. [7] have monitored 37 pharmaceutical residues in 8 surface waters and drinking waters, in western France, and the highest drug concentrations were reported for ketoprofen, hydroxy-ibuprofen, acetaminophen, caffeine and danofloxacin. Despite these concentrations in aquatic systems, as resources for the production of drinking waters, risks for human health were considered negligible [1] [8]. However, risk assessments are still discussed following some authors [9] [10].

Adsorption-based technologies are recognized as efficient, promising treatment alternatives that are widely used in water and wastewater treatment for the removal of organic micropollutants such as pharmaceutical residues and pesticides[11] [12] [13]. In practice, granular activated carbon (GAC) [14] and/or powdered activated carbon (PAC) are used to eliminate organic pollutants. According to Rigobello et al. [15] and Sotelo et al. [16] the adsorption capacities of diclofenac at high concentrations, onto granular activated carbon are about $230 \mathrm{mg} \cdot \mathrm{g}^{-1}$ for a residual aqueous concentration of $40 \mathrm{mg} . \mathrm{L}^{-1}$. For carbamazepine, Cai and Larese-Casanova [17] found capacities of 200 $\mathrm{mg} \cdot \mathrm{g}^{-1}$ onto granular activated carbon for a residual concentration of $0.5 \mathrm{mg} \cdot \mathrm{L}^{-1}$. 
Activated carbon fiber cloths (ACFC) have been studied for water treatment [18] [19]. The advantages of such textiles are their high specific surface areas, predominantly microporous texture and large adsorption capacities [20] [21]. Therefore, ACFC were more efficient in terms of adsorption rate and selectivity than granular activated carbon for the removal of aromatic compounds [16] [22]. However, to our knowledge, few studies have dealt with the adsorption of pharmaceutical residues and pesticides onto ACFC [23] [24], especially at trace concentrations. However, supplementary informations are required in order to understand how activated carbon cloths behave at low concentrations of pollutants in presence of natural organic matter.

Nowadays, adsorption processes are most often designed on the basis of the amount adsorbed at equilibrium with the inlet concentration of the micropollutants. Therefore, isotherms of adsorption should be carefully modeled taking into account experimental errors, the type of model and error function [25] [26] [27]. Special care should be paid when dealing with trace concentrations and the extrapolation of isotherm models [28]. Even with realistic and relevant adsorption capacities at trace concentrations, the impact of the nature of Natural Organic Matter (NOM) should be considered, particularly in the presence of low molecular components of NOM [29]. Moreover, adsorption capacities from isotherms conducted in batch reactors were shown to overestimate the adsorption capacities for breakthrough curves [30]. Although the impact of NOM is complex, two main mechanisms could be distinguished. the site competition with a strongly competing equivalent NOM compound and/or the pore blockage occurring with larger NOM compounds [31][32].

The aim of this study is to evaluate the efficiency of ACFC for the removal of 8 emerging pollutants in mixture. Batch reactors were carried out to study the kinetics and adsorption capacities of ACFC to remove micropollutants in different kinds of waters (ultrapure, ground water and half diluted groundwater). Kinetic experimental data were compared to the most frequently models used (HSDM) in a multicomponent solution (IAST model). 


\section{Materials and methods}

\subsection{Materials}

\subsubsection{Organic compounds}

The targeted compounds - acetaminophen, caffeine, carbamazepine, diclofenac, ofloxacine, ibuprofen, mecoprop, bisphenol A and benzotriazol - were all purchased from Sigma-Aldrich (purity $>98 \%$ ). The physicochemical properties and molecular structures of the compounds are listed in Table 1. Stock solutions $\left(10 \mathrm{mg} . \mathrm{L}^{-1}\right)$ were prepared by dissolving the commercial standard in ultrapure water (UPW) provided by an ElgaPureLab System $(18.2 \mathrm{M} \Omega . \mathrm{cm})$. The experiments were carried out at low concentrations $\left(\mathrm{C}_{0}=10 \mu \mathrm{g} \cdot \mathrm{L}^{-1}\right)$. The experiments were achieved respectively in ultrapure water (UPW), groundwater (GW) and groundwater diluted (1/2 vol.) by ultrapure water (GW/2).

Analyses of the selected compounds were performed using UHLPC with an Acquity system (Waters) coupled with a tandem mass spectrometer (Quattro Premier, Micromass), the method was extensively describe elsewhere [31] [32]. Briefly, the chromatographic system included a 2777 autosampler (Waters) equipped for dual on-line solid phase extraction (on-line SPE) with HLB cartridges. $5 \mathrm{~mL}$ of sample was loaded onto the HLB cartridges using a large volume injection loop and a quaternary solvent pump (QSM - Waters). After the loading and cleaning steps, HLB cartridges were connected to the BEH C18 analytical column $(100 \times 2.1 \mathrm{~mm} \times 1.7 \mu \mathrm{m}$, Waters $)$ thermostatic at $45^{\circ} \mathrm{C}$. The binary gradient consist of a mixture of acetonitrile as mobile phase A, and acetonitrile/water/formic acid $(10: 90: 0.1, \mathrm{v} / \mathrm{v} / \mathrm{v})$ as mobile phase $\mathrm{B}$. The separation was initiated at a constant flow of $0.4 \mathrm{ml} \cdot \mathrm{min}^{-1}$, 
followed by a decrease in B to $10 \%$ within $7 \mathrm{~min}$. This composition was then maintained for $10 \mathrm{~min}$ and returned to the initial composition.

Mass spectrometry was used with an electrospray ionization source in positive or negative mode with a capillary voltage of $3 \mathrm{kV}$ and nitrogen as the nebulizer and drying gas. The cone gas flow and the desolvation gas flow were set at $50 \mathrm{~L} \cdot \mathrm{h}^{-1}$ and $750 \mathrm{~L} \cdot \mathrm{h}^{-1}$, respectively. The source temperature and desolvation temperature were $120^{\circ} \mathrm{C}$ and $350^{\circ} \mathrm{C}$, respectively. The multiple reaction monitoring (MRM) mode was used for the quantification of all compounds. Retention time, MRM transitions, cone voltage and collision cell energy are summarized in Table 1. To avoid matrix effects, quantification has been done using standard addition method previously described [33]. 
Table 1 : Properties of pollutants used in adsorption procedures at neutral pH

\begin{tabular}{|c|c|c|c|c|c|c|c|c|}
\hline 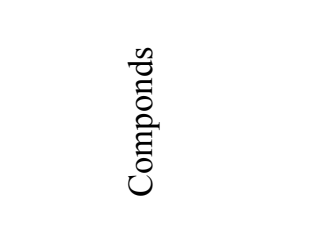 & 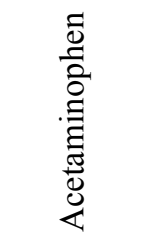 & 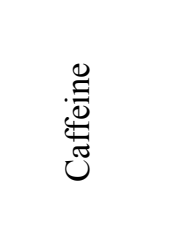 & $\begin{array}{l}\mathscr{0} \\
\frac{\pi}{0} \\
\frac{0}{0} \\
\frac{0}{0} \\
0\end{array}$ & 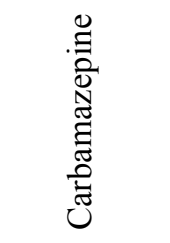 & 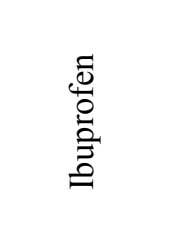 & 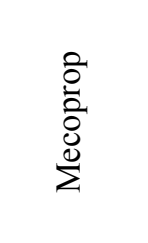 & $\frac{7}{\frac{D}{2}} \frac{\pi}{3}$ & $\begin{array}{l}0 \\
0 \\
0 \\
\text { Ẽ } \\
0 \\
0 \\
0 \\
0\end{array}$ \\
\hline $\mathrm{N}^{\circ} \mathrm{CAS}$ & $103-90-2$ & 58-08-2 & $15307-86-5$ & $298-46-4$ & $15687-21-1$ & $-65-2$ & $0-05-7$ & $95-14-7$ \\
\hline Structure & $\mathrm{C}_{8} \mathrm{H}_{9} \mathrm{NO}_{2}$ & $\mathrm{C}_{8} \mathrm{H}_{9} \mathrm{~N}_{4} \mathrm{O}_{2}$ & $\begin{array}{c}\mathrm{C}_{14} \mathrm{H}_{11} \mathrm{Cl}_{2} \mathrm{~N} \\
\mathrm{O}_{2}\end{array}$ & $\mathrm{C}_{15} \mathrm{H}_{12} \mathrm{~N}_{2} \mathrm{O}$ & $\mathrm{C}_{13} \mathrm{H}_{18} \mathrm{O}_{2}$ & & $\mathrm{C}_{15} \mathrm{H}_{16} \mathrm{O}_{2}$ & $\mathrm{C}_{6} \mathrm{H}_{5} \mathrm{~N}_{3}$ \\
\hline $\mathrm{MW}\left(\mathrm{g} \cdot \mathrm{mol}^{-1}\right)$ & 151.16 & 194.19 & 296.15 & 236.27 & & 214.65 & 228.29 & 119.12 \\
\hline $\mathrm{pKa}_{1} / \mathrm{pKa}_{2}$ & 9.5 & $1.2 / 14$ & 4.2 & $2.3 / 14$ & & 3.9 & 9.6 & $0.6 / 8.3$ \\
\hline Log Kow & 0.46 & -0.07 & 4.51 & 2.45 & & 3.13 & 3.32 & 1.44 \\
\hline Solubility (g. $\left.\mathrm{L}^{-1}\right)$ & 14.9 & 21.7 & $2.4 .10^{-3}$ & 11.1 .10 & $21 \cdot 3 \cdot 10^{-3}$ & $7.3 .10^{-1}$ & $1.2 .10^{-1}$ & 19.8 \\
\hline Cone voltage (V) & 25 & 37 & 22 & & 17 & 30 & 40 & 30 \\
\hline $\begin{array}{l}\text { Collision energy } \\
\qquad(\mathrm{eV})\end{array}$ & 15 & 18 & & & 7 & 18 & 19 & 16 \\
\hline Transition & $152>110$ & $195>138$ & & $237>194$ & $205>161$ & $213>141$ & $227>212$ & $120>92$ \\
\hline Retention time (min) & 1.49 & & & 3.61 & 3.39 & 1.79 & 4.27 & 1.90 \\
\hline
\end{tabular}

\subsubsection{Ground water compositions}

Groundwater (GW) came from infiltration in the well located on the campus of the Ecole Nationale

Superieure de Chimie de Rennes, France. Seasonal analyses were performed for the total organic content (DOC). The DOC was shown to vary from 1.5 and $5.7 \mathrm{mg}_{\mathrm{c}} \cdot \mathrm{L}^{-1}$. As illustrated in Table 2, the resistivity of the GW is relatively high and indicates that the minerals of water were quite low. GW was filtered through cellulose membranes $(0.7 \mu \mathrm{m})$, to remove suspended solids and colloids before use. . The characteristics of ultrapure and groundwater are presented in Table 2. 
Table 2 : Physicochemical properties of waters (values in brackets are seasonal standard deviations)

\begin{tabular}{|c|c|c|}
\hline & Ultrapure water (UPW) & Groundwater(GW) \\
\hline $\mathrm{pH}$ & 6.8 & $6.4(0.1)$ \\
\hline Resistivity (M $\Omega . \mathrm{cm})$ & 18.2 & $0.5(0.02)$ \\
\hline $\begin{array}{c}\text { Absorbance } \mathrm{UV}_{254}\left(\mathrm{~cm}^{-}\right. \\
\left.{ }^{1}\right)\end{array}$ & $<0.003$ & 0.039 \\
\hline $\mathrm{DOC}\left(\mathrm{mg}_{\mathrm{C}} \cdot \mathrm{L}^{-1}\right)$ & $<50.10^{-3}$ (detection limit) & $2.9(0.8)$ \\
\hline SUVA $\left(L \cdot m_{C}{ }^{-1} \cdot m^{-1}\right)$ & & \\
\hline
\end{tabular}

\subsubsection{Activated carbon fiber cloth (ACFC)}

The ACFC (commercial name: KI-P-1200) was supplied by Dacarb (Asnières-sur-Seine, France). It was washed as received in ultrapure water to remove any dissolved contaminants and/or fine particles and then dried at $120{ }^{\circ} \mathrm{C}$ prior to the experiments. The physical and chemical characteristics of the ACFC are given in Table 3. The physisorption of nitrogen at $77 \mathrm{~K}$ (Autosorb, Quantachrome Instruments) was used to determine the specific internal surface area (multi-point BET method in the range of relative pressures 0.01 to 0.1 ), the total pore volume (relative pressure of 0.995 ), the micropore volume and the average pore size (Quenched Solid State Density Functional Theory, QSDFT) [34][35]. In addition, the Boehm titration method was used to quantify the surface functional groups [36]. The ACFC possesses a highly microporous texture (over $90 \%$ of the total pore volume) and few functional groups in comparison to common granular activated carbons [37]. This specificity was confirmed by the residual $\mathrm{pH}$ (measured after $24 \mathrm{~h}$ in ultrapure water), which was close to neutrality and in agreement with the balance between acidic and basic groups. These characteristics are summarized in Table 3. 
Table 3 : Physical and chemical properties of the ACFC

Textural properties from $\mathrm{N}_{2}$ adsorption at $77 \mathrm{~K}$
Specific surface area $\left(\mathrm{m}^{2} \cdot \mathrm{g}^{-1}\right)$
Total pore volume $\left(\mathrm{cm}^{3} \cdot \mathrm{g}^{-1}\right)$
Micropore volume $(\mathrm{QSDFT})\left(\mathrm{cm}^{3} \cdot \mathrm{g}^{-1}\right)$
Micropore size $(\mathrm{QSDFT})(\mathrm{nm})$
Chemical surface properties from Boehm titration
Residual $\mathrm{pH}$
Basic functions $\left(\mu \mathrm{eq} \cdot \mathrm{L}^{-1}\right)$
Carboxylic acid functions $\left(\mu \mathrm{eq} \cdot \mathrm{L}^{-1}\right)$
Lactone functions $\left(\mu \mathrm{eq} \cdot \mathrm{L}^{-1}\right)$
Phenolic functions $\left(\mu \mathrm{eq} . \mathrm{L}^{-1}\right)$

\subsection{Adsorption kinetics and isotherms}

Kinetic curves of adsorption were performed for all compounds in mixture, both in ultrapure and natural ground waters. For that purpose, $10 \mathrm{~L}$ reactors were used and the initial concentration was 10 $\mu \mathrm{g} . \mathrm{L}^{-1}$ of each compound. Preliminary experiments demonstrated that inter-component adsorption competition was not significant if the initial concentration was lower than $10 \mu \mathrm{g} . \mathrm{L}^{-1}$ (as illustrated on Figure 1 - example for acetaminophen). 


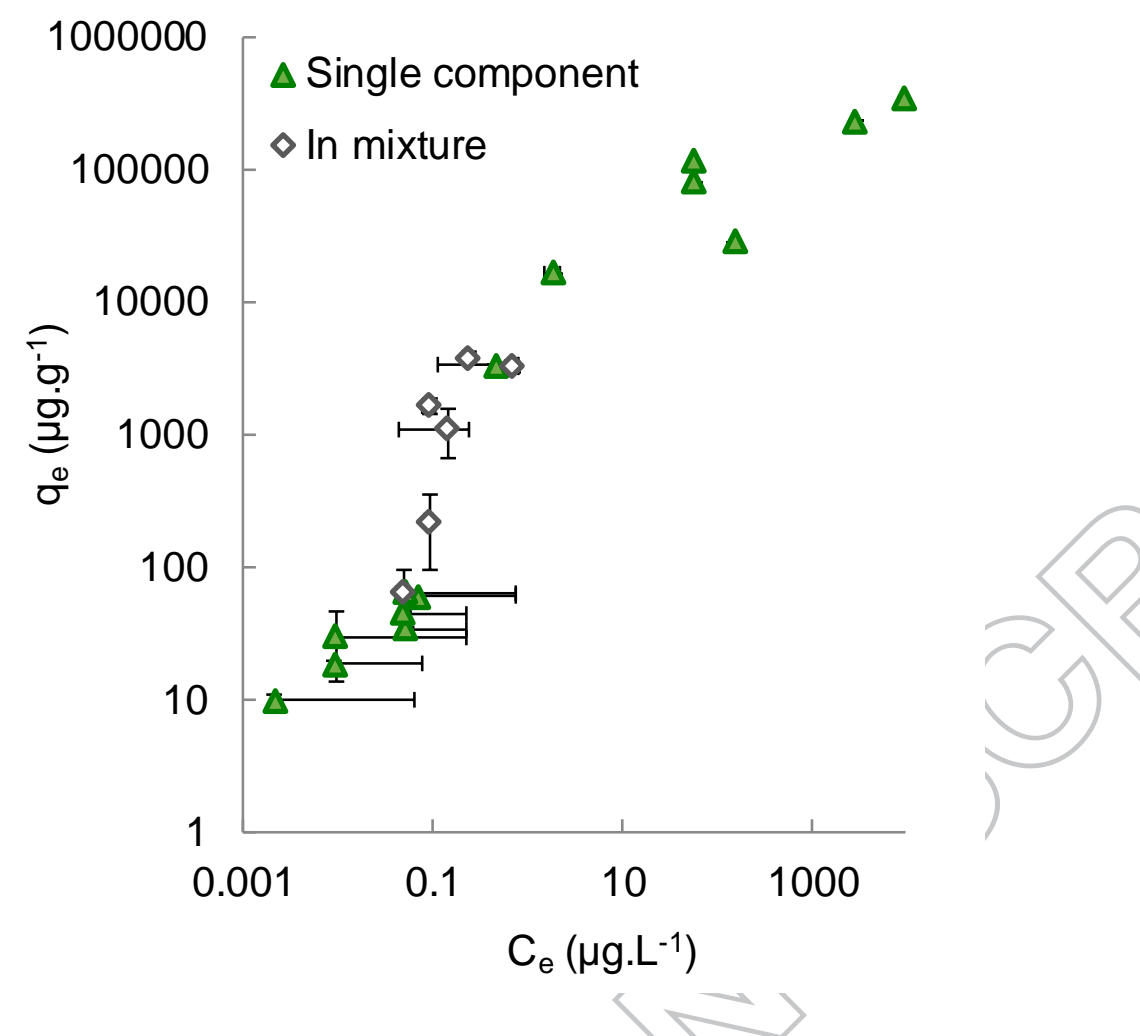

Figure 1. Adsorption of acetaminophen in UPW onto ACFC

(in single-component solution and in mixture)

The $\mathrm{pH}$ was maintained at 7.5 using hydrogen carbonate buffer and did not vary more than $0.1 \mathrm{pH}$ unit between the initial and final time of the experiment. A temperature of $25^{\circ} \mathrm{C}$ was kept constant using a thermostatic bath. A constant mass of ACFC $(20 \pm 0.2 \mathrm{mg})$ was then incorporated and the reactors were tightly sealed and homogenized using a magnetic stir bar at $400 \mathrm{rpm}$. The supernatant were filtered using a $0.2 \mu \mathrm{m}$ GHP Acrodisc filter prior to analysis by SPE-UPLC/ MS-MS in order to determine the residual concentration $\left(\mathrm{C}_{\mathrm{i}}\right)$ and adsorption capacities $\left(\mathrm{q}_{\mathrm{i}}\right)$ according to the mass balance.

\subsection{Modelling of multicomponent adsorption}

The significant content of NOM in the natural water implied taking into account the competition of adsorption between the target compounds and the NOM. Competitive adsorption equilibria were modeled using the ideal adsorbed solution theory (IAST) (see equations Table 4), originally established by Radke and Prausnitz [38] for dilute aqueous solutions. Strictly, IAST requires the individual isotherm model for each component. However, assuming a non-interaction between molecules at low concentrations in mixture in ultrapure water, we consider the data obtained in these 
conditions as individual isotherm values for each component. On one hand, the Langmuir-Freundlich model was used for each micropollutant, with parameters adjusted independently. On the other hand, the adsorption of NOM has to be described through an isotherm too. One possibility is to implement a single isotherm for pure NOM (for instance, measuring the residual DOC content after adsorption onto activated carbon). Another approach was used in this study. Indeed, NOM was considered as a single competing compound for the adsorption of each micropollutant. This methodology enables the distinction between the target compounds since NOM can have different impacts depending on the target compound (different locations in the porosity, pore blockage, modifications of the affinity between the adsorbate and the carbon surface). Consequently, the approach consists in representing $\mathrm{NOM}$ as an Equivalent Background Compound (named EBC) [39][40]. The competition becomes a co-adsorption between the target pollutant and the EBC [39][41][42][43][44]. In this case, the Langmuir-Freundlich equation was applied to the adsorption of the EBC and consequently, three parameters $\left(\mathrm{q}_{\mathrm{m}}, \mathrm{b}\right.$ and $\left.\mathrm{n}\right)$ should be fitted. Moreover, the initial concentration of the EBC is unknown. In order to improve the reliability of the adjustment procedure, adsorption isotherms were carried out in ground water as well as in half-diluted groundwater (which corresponds to an initial concentration of the EBC divided by 2).

Furthermore, in combination with the IAST, the homogeneous surface diffusion model (HSDM) [45] (Table 5) was used to describe the kinetics of adsorption. The inner diffusion equation for a sphere was used in the set of equations. In fact, the ACFC has a complex geometry with contacts between yarns formed from fibers. The external surface is difficult to define. It has to be stressed that the HSDM was used using the yarn as the elemental geometry for mass transfer, although the ACFC has a dual scale with yarns of $430 \mu \mathrm{m}$, made themselves of $10 \mu \mathrm{m}$ fibers. Previous work concluded that external mass transfer was occurring at the outer surface of the yarn [27]. The Langmuir-Freundlich as the isotherm model was applied. This model was the most predictive model among 3 tested models (Freundlich, Langmuir and Langmuir-Freundlich equations) [27].

The calculations and applications of HSDM and IAST were performed with a software developed previously [40]. 


\begin{tabular}{|c|l|l|}
\hline Equation & $\mathrm{n}^{\circ}$ & \multicolumn{1}{|c|}{ Role } \\
\hline$q_{T}=\sum_{i=1}^{n} q_{i}$ & 1 & $\begin{array}{l}\text { Concentrations in the solid } \\
\text { phase }\end{array}$ \\
\hline$z_{i}=\frac{q_{i}}{q_{T}}$ & 2 & $\begin{array}{l}\text { Molar fraction in the adsorbed } \\
\text { phase }\end{array}$ \\
\hline$\frac{1}{q_{T}}=\sum_{i=1}^{n} \frac{z_{i}}{q_{i}^{0}}$ & 3 & $\begin{array}{l}\text { Non selectivity of the } \\
\text { homogeneous surface }\end{array}$ \\
\hline$\sum_{i=1}^{n} \frac{q_{i}}{q_{i}^{0}}=1$ & & \\
\hline$C_{i}=z_{i} C_{i}^{0}\left(\pi_{m}\right)$ & & $\begin{array}{l}\text { Equality of spreading pressure } \\
\text { of mixture versus pure ideal } \\
\text { solution }\end{array}$ \\
\hline$\pi_{i}\left(C_{i}^{0}\right)=\pi_{m}=\frac{R T}{A} \int_{0}^{C_{i}^{0}} \frac{q_{i}^{0}}{C_{i}^{0}} d C_{i}^{0}=\frac{R T}{A} \int_{0}^{q_{i}^{0}} \frac{d \ln C_{i}^{0}}{d \ln q_{i}^{0}} d q_{i}^{0}$ & 5 & Isotherm adsorption equation \\
\hline$q_{i}^{0}=f\left(C_{i}^{0}\right)$ & $\begin{array}{l}\text { Langmuir-Freundlich equation } \\
\frac{q_{e i}}{q_{m i}}=\frac{\left(b C_{e i}\right)^{n}}{1+\left(b C_{e i}\right)^{n}}\end{array}$ & \\
\hline
\end{tabular}

Table 4 Equations for the Ideal Adsorbed Solution Theory (IAST)

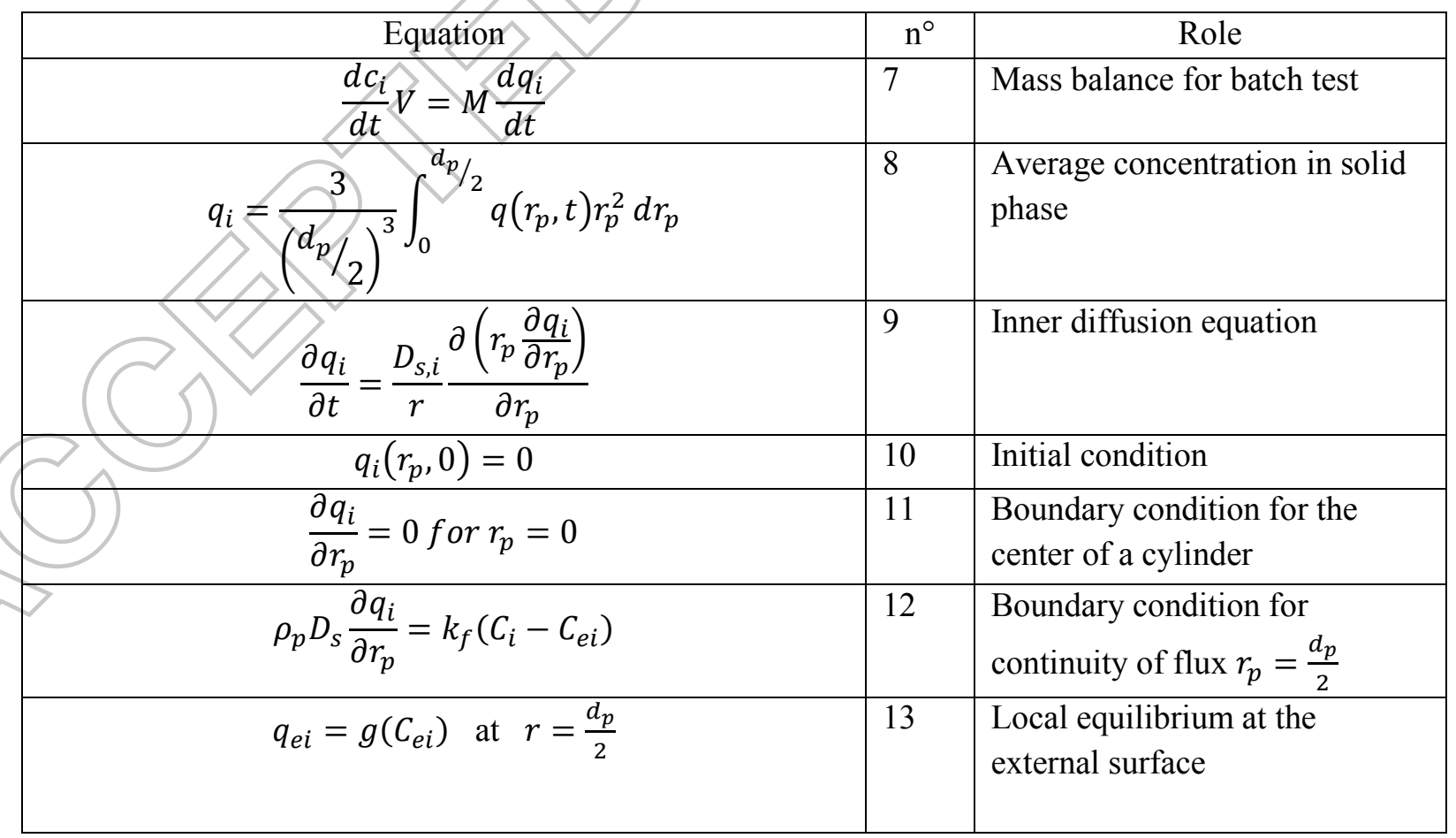




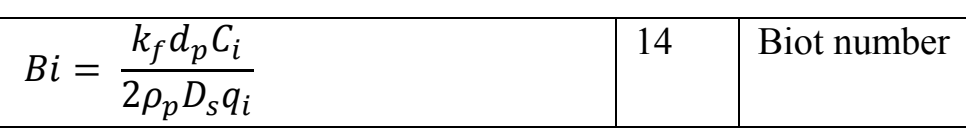

Table 5 Set of equations for the Homogeneous Surface Diffusion Model (HSDM)

\section{Results}

\subsection{Kinetics of adsorption}

Kinetic studies are essential to determine the required time to reach the equilibrium especially in ACFC where the kinetics are very fast compared to activated carbon or powder due to a large external surface [18] [19]. Moreover, the change in aqueous concentration against time was used to compute the mass transfer coefficients for each pollutant/adsorbent system. Matthews and Weber [46] proposed a two-step resistance. This homogeneous surface diffusion model (HSDM) supposes that the two limiting steps are the diffusion through the external layer surrounding the particle and surface diffusion inside the porosity. Thus, two coefficients can be calculated (i) $K_{f}$, which represents the external mass transfer, and (ii) Ds, which corresponds to the surface diffusivity. For each adsorbate/adsorbent couple studied, these two coefficients were calculated in ultrapure and half diluted groundwater and non-diluted groundwater water (Table 6) using an iterative optimization procedure which consists to minimize the error function $\left(E=\frac{1}{n} \sqrt{\left(\frac{q_{i-q_{i m o d}}}{q_{i}}\right)^{2}}\right)$ using the excel solver function [27].

Figure 2 shows the kinetics of adsorption in ultrapure water (UPW), ground water (GW) and groundwater diluted by two with ultrapure water $(\mathrm{GW} / 2)$ with a starting concentration of $10 \mu \mathrm{g} . \mathrm{L}^{-1}$. As observed for the carbamazepine, some compounds were largely impacted by the presence of NOM, and these kinetic competition effects were similarly observed with diclofenac, caffeine, acetaminophen and ibuprofen. At the opposite, the rate of adsorption of benzotriazole, mecoprop and bisphenol A was slightly reduced in the presence of NOM. It clearly indicates that competitions for adsorption sites as well as pore blocking depend on the nature of micropollutants as shown by Snoeying and Coll. [47] [48]. 

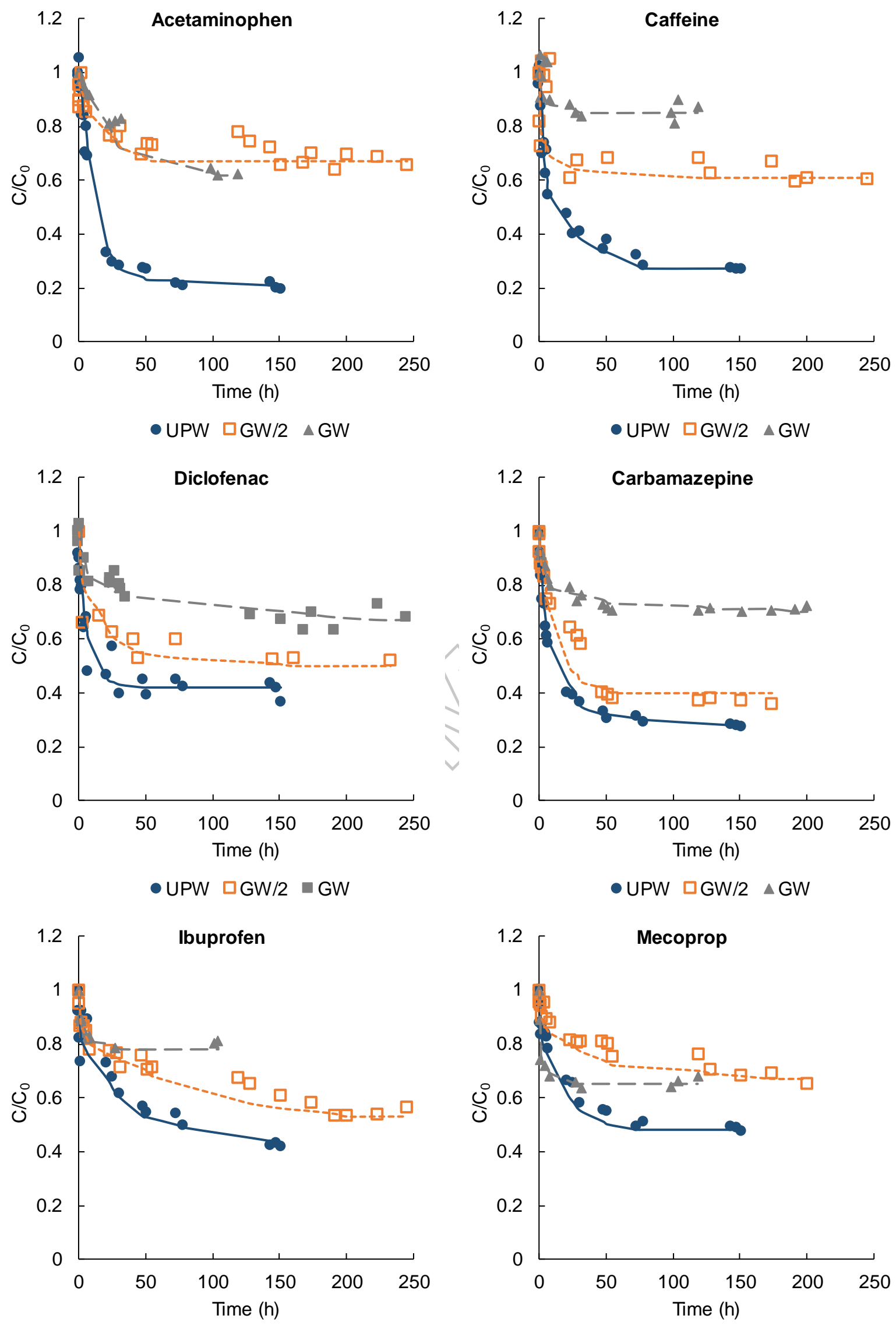

- UPW $\square \mathrm{GW} / 2 \triangle \mathrm{GW}$

- UPW $\square \mathrm{GW} / 2 \triangle \mathrm{GW}$ 

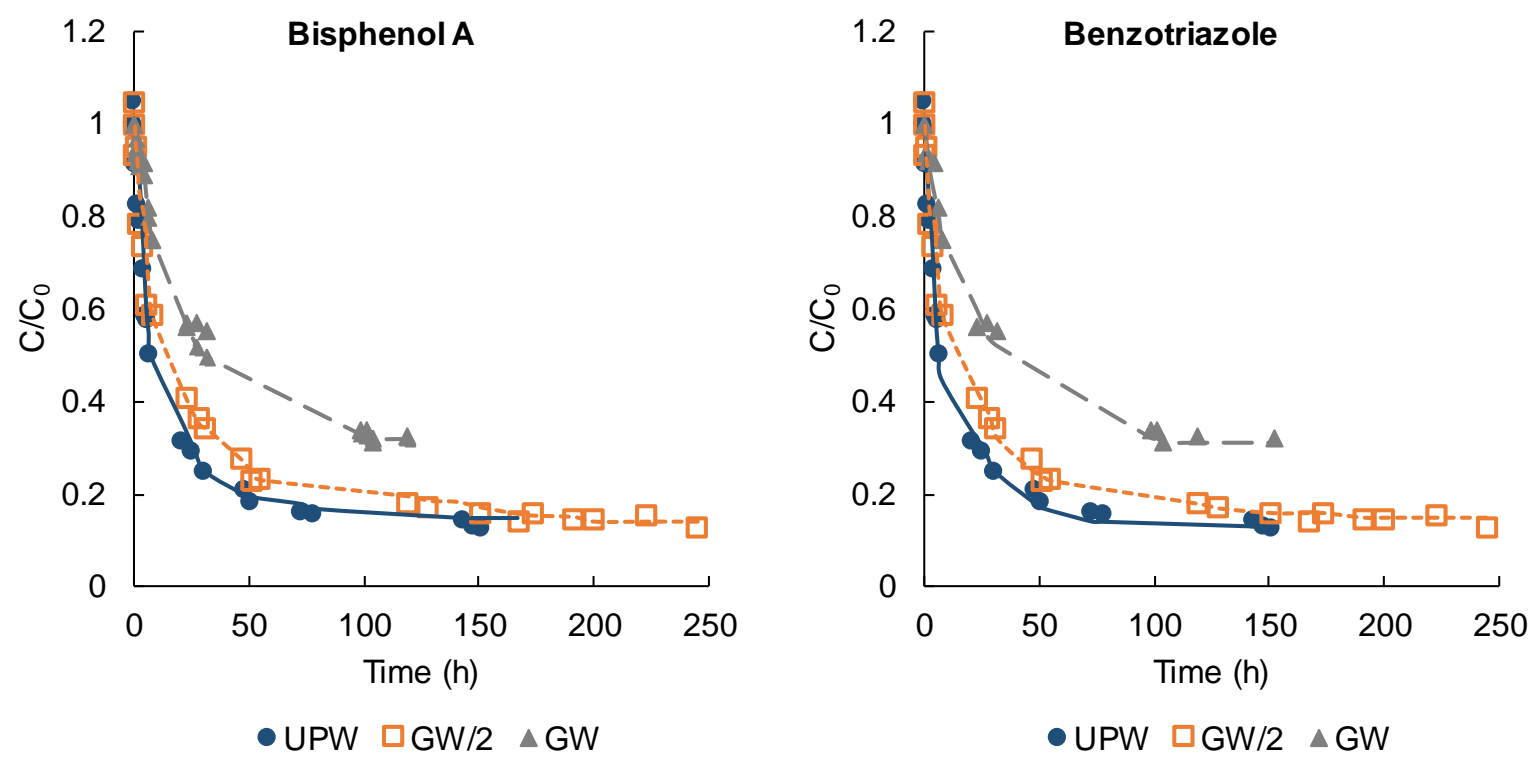

Figure 2. Kinetics of adsorption of the 8 micropollutants $\left(\mathrm{C}_{0}=10 \mu \mathrm{g} . \mathrm{L}^{-1}\right)$ in ultrapure, diluted $(1 / 2)$ groundwater and groundwater (Line corresponds to the prediction with the IAST - HSDM models)

Table 6. Mass transfer coefficients from HSDM adjustment on the kinetics of adsorption at $\mathrm{C}_{0}=$ $10 \mu \mathrm{g} . \mathrm{L}^{-1}$ of micropollutants (values in italic indicate negligible mass transfer resistance)

\begin{tabular}{|c|c|c|c|c|c|c|}
\hline & & pure & & & rground & \\
\hline & & $\begin{array}{c}\mathbf{K}_{\mathbf{f}} \\
\left(\mathbf{m} . \mathbf{s}^{-1}\right)\end{array}$ & $\begin{array}{c}\text { Biot } \\
\text { number }\end{array}$ & $\begin{array}{c}D_{s} \\
\left(\mathbf{m}^{2} \cdot \mathbf{s}^{-1}\right)\end{array}$ & 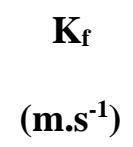 & $\begin{array}{c}\text { Biot } \\
\text { number }\end{array}$ \\
\hline Caffeine & $4.4 .10^{-10}$ & $1.0 .10^{2}$ & 32609 & $6.1 .10^{-9}$ & $4.2 \cdot 10^{-2}$ & 3 \\
\hline Acetan & $1.1 .10^{-9}$ & $4.1 .10^{-2}$ & 2 & $2.5 \cdot 10^{-10}$ & $9.6 \cdot 10^{-3}$ & 3 \\
\hline Diclof & $1.3 .10^{-9}$ & $2 \cdot 9 \cdot 10^{-1}$ & 867 & $4 \cdot 2 \cdot 10^{-12}$ & $6.5 \cdot 10^{-2}$ & 76521 \\
\hline Carbamazepine & $1.4 .10^{-9}$ & $7.4 .10^{-2}$ & 7 & $2.1 .10^{-10}$ & $1.1 .10^{-1}$ & 867 \\
\hline Ibuprofen & $4.4 .10^{-10}$ & $1.4 .10^{2}$ & 177170 & $8.5 .10^{-10}$ & $7.4 \cdot 10^{-2}$ & 56 \\
\hline Mecoprop & $1.2 .10^{-10}$ & $2.9 \cdot 10^{-2}$ & 7 & $9.9 .10^{-10}$ & $8.5 \cdot 10^{-2}$ & 12 \\
\hline Benzotriazole & $4.4 .10^{-10}$ & $3.9 \cdot 10^{-2}$ & 3 & $9.6 .10^{-10}$ & $1.6 .10^{-2}$ & 10 \\
\hline Bisphenol A & $1.2 .10^{-11}$ & $1.4 .10^{-2}$ & 238 & $9.8 .10^{-12}$ & $8.9 .10^{-2}$ & 857 \\
\hline
\end{tabular}


In Table 6, considering the Biot numbers (dimensionless ratio of the rate of external transfer to the surface diffusion), two situations occurred. If Biot numbers were higher than 500 (for example, for carbamazepine or ibuprofen in ultrapure water), superficial diffusion was the only limiting mechanism. For these cases, the coefficient $K_{\mathrm{f}}$ had no statistical significance and there was no resistance to mass transfer in the boundary layer around the yarns. If Biot numbers were between 1 and 100, both mechanisms (external and inner diffusion) co-existed as limiting steps for the mass transfer. From data summarized in Table 6, four behaviors could be distinguished in the presence of NOM:

- For mecoprop, acetaminophen and benzotriazole, NOM had a negligible influence on Biot numbers. Regardless of the aqueous matrix, both mechanisms exist.

- Bisphenol A exhibited Biot number higher than 100, in both ultrapure and natural waters (i.e. in the presence or absence of NOM). Then, superficial diffusion was the only limiting mechanism.

- For carbamazepine and diclofenac, in ultrapure water, values were between 1 and 100, whereas, in natural water, Biot number became larger 100, and superficial diffusion became the limiting mechanism when NOM was competing for adsorption.

- For caffeine and ibuprofen, the opposite behavior was found with only surface diffusion ultrapure water, and the addition of external mass transfer resistance in the presence of NOM.

In Table 6, the surface diffusivities were shown to remain in the same order of magnitudes, and did not depend on the presence or absence of NOM [42] [43]. We assume a pore clogging due to NOM as shown in several previous works [47] [48] and not a real adsorption competition in the same sites between micropollutant and NOM. The only exception is diclofenac, for which the surface diffusivity decreased from $1 \cdot 3 \cdot 10^{-9}$ to $4 \cdot 2 \cdot 10^{-12} \mathrm{~m}^{2} \cdot \mathrm{s}^{-1}$ from ultrapure to ground waters, respectively. 


\subsection{Isotherms of adsorption}

Isotherms of adsorption were determined in ultrapure water (UPW), in ground water diluted two times by UPW (GW/2) and undiluted ground water $(\mathrm{GW})$. The isotherm curves are presented on Figure 3. Each isotherm was modeled using the Langmuir-Freundlich model (Tables 7 and 8$)^{49}$ its parameters were adjusted by minimizing the relative error (E) (see equation 15 between simulated $\left(\mathrm{q}_{\mathrm{e}, \mathrm{mod}}\right.$ ) and experimental $\left(\mathrm{q}_{\mathrm{ei}, \text { exp }}\right)$ data according to the equation 1 and 2 [27]. In case of natural groundwater, the IAST was used in which the NOM was considered as an EBC.

$$
E=\frac{1}{n} \sum_{i=1}^{n} \frac{\left|q_{e i, \text { mod }}-q_{\text {ei,xep }}\right|}{q_{\text {ei,exp }}}
$$



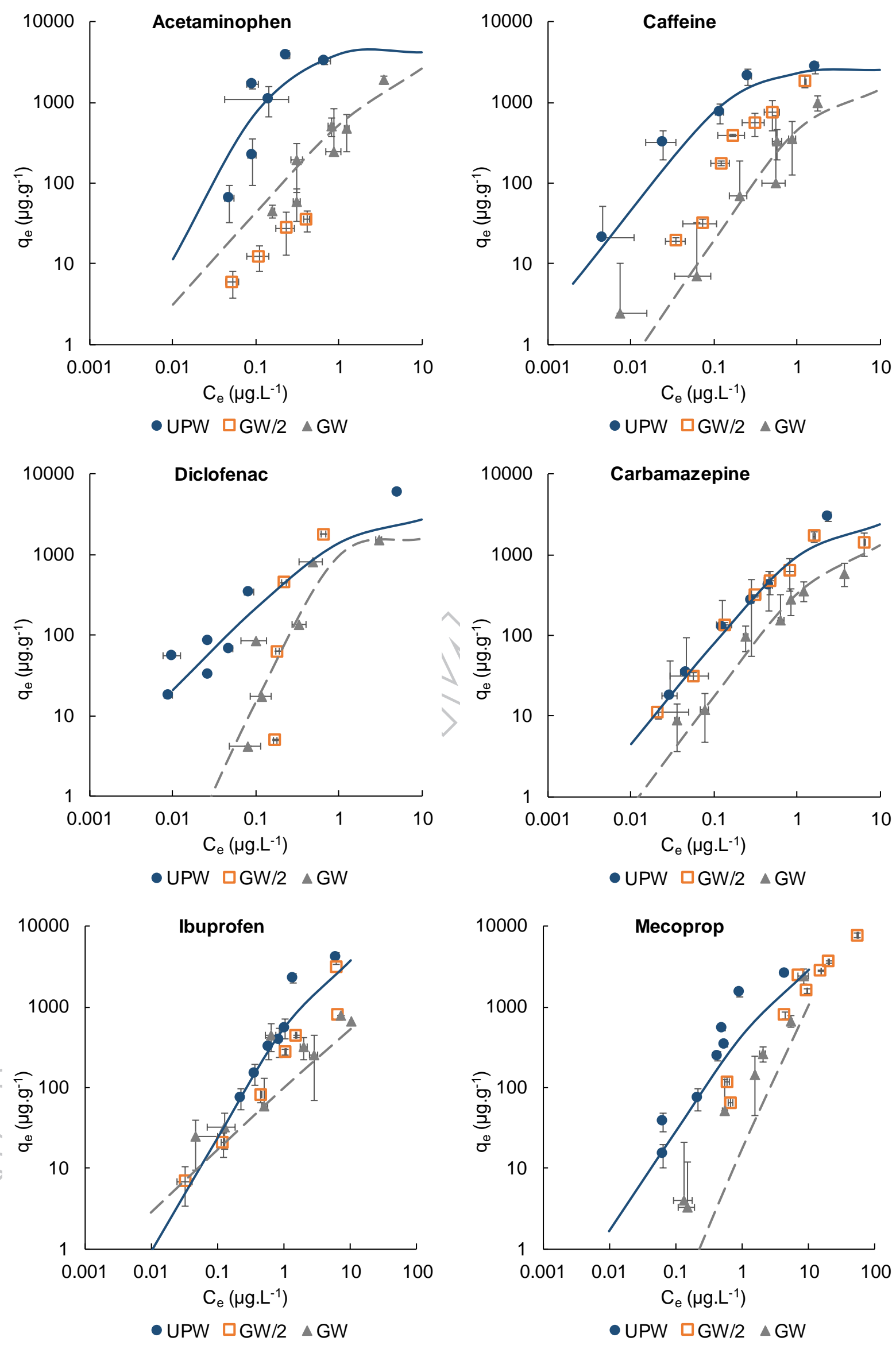

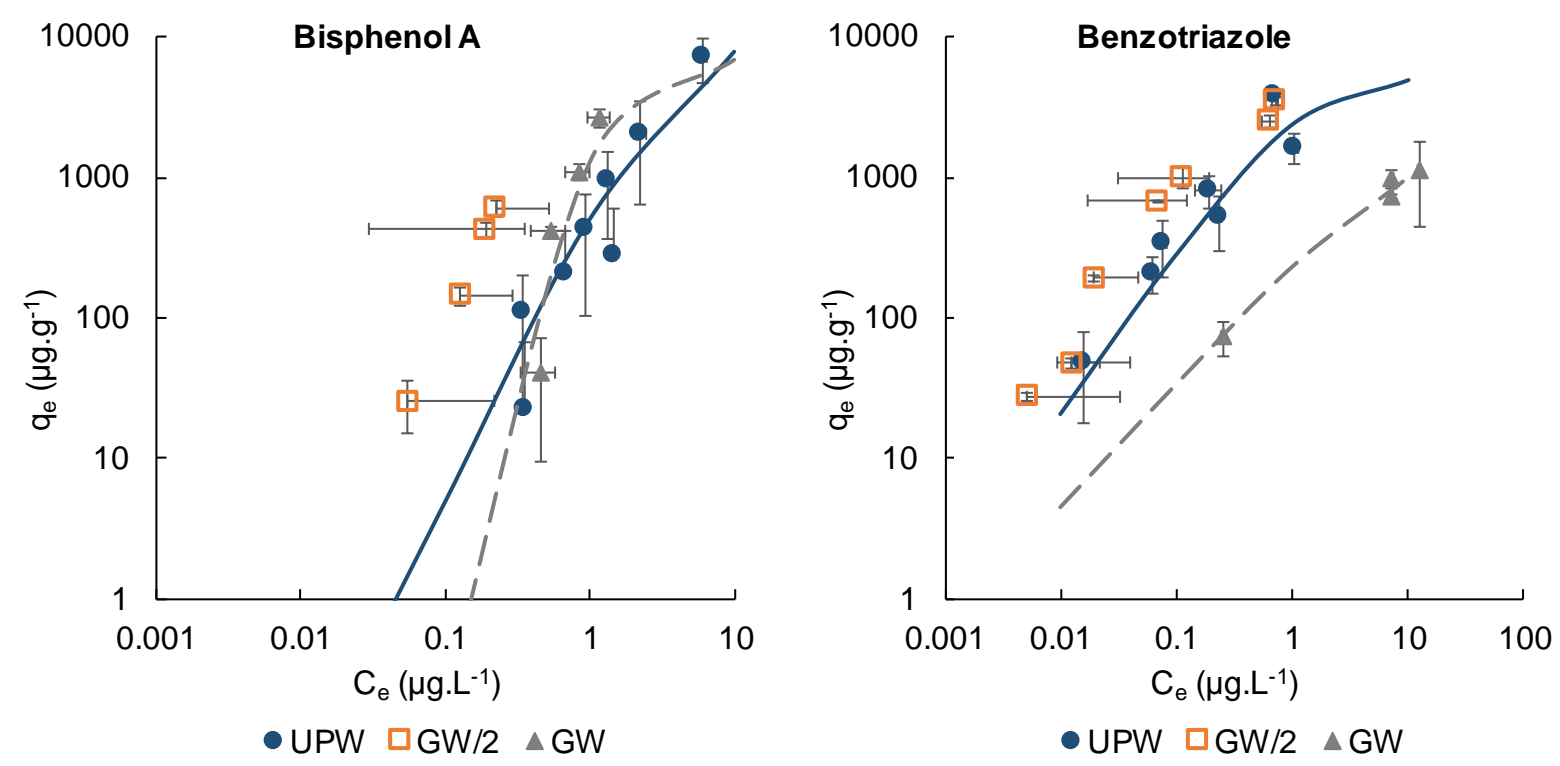

Figure 3 : Isotherms of adsorption of 8 micropollutants in ultrapure, diluted groundwater $(1 / 2)$ and ground waters. Initial concentrations between $10 \square \mathrm{g} / \mathrm{L}$ and $10 \mathrm{mg} / \mathrm{L}$. Lines correspond to the IAST model.

The adsorption capacities found previously at high concentrations were found previously around 200 $250 \mathrm{mg} / \mathrm{g}$ for a concentration at equilibrium close to $20-40 \mathrm{mg} / \mathrm{L}$ [15] [16] [17]. In the present study, the adsorption capacities at very low concentration in the solution (Figure 3) are of the order of a few hundred $\square \mathrm{g} \mathrm{g}^{-1}$ for a concentration in the solution at the equilibrium ranging 10 to $0.01 \square \mathrm{g} / \mathrm{L}$. From Figure 3, two types of results are shown. On one hand, for carbamazepine, Ibuprofen and benzotriazole, the impact of NOM was negligible for diluted ground water whereas the impact was important when non-diluted ground water was used. In those cases, the competition with NOM exhibited a threshold effect, i.e. the NOM content should exceed a certain amount for adsorption competitions to take place [40]. On the other hand, for caffeine and mecoprop, the impact of NOM was gradual when shifting from diluted to non-diluted ground water.

In order to assess the impact of NOM on adsorption capacities, it was chosen to compare the capacities for a given residual concentration of each micropollutant $(0.1 \mu \mathrm{g} / \mathrm{L})$. Results are gathered in Table 7 . 
Table 7 : Adsorption capacities for a residual concentration of $0.1 \mu \mathrm{g} . \mathrm{L}^{-1}$ and impacts of natural water

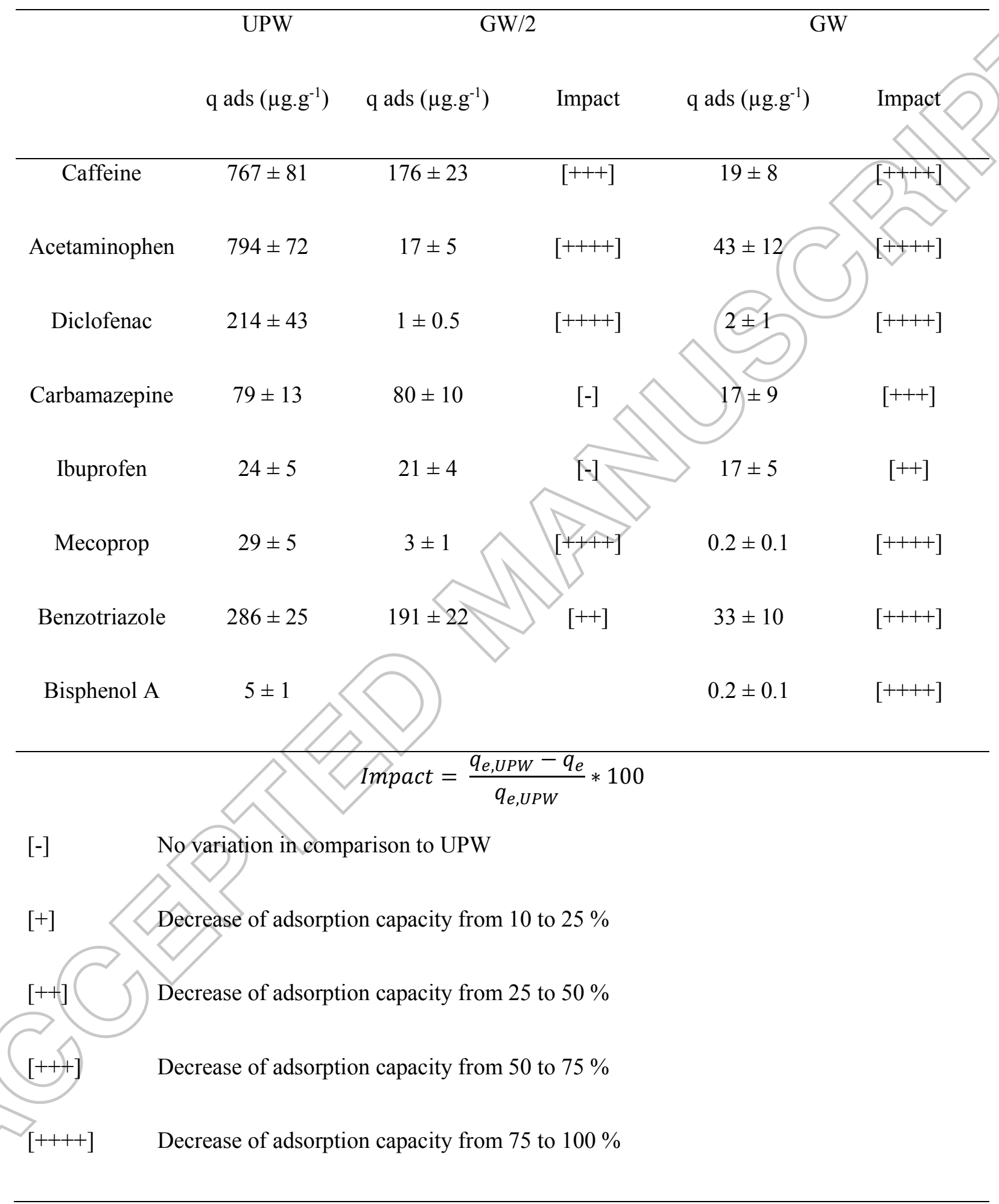


Results in Table 8 show an important decrease of adsorption capacities in ground water, i.e., in the presence of NOM. For most of compounds, the diminution is over $75 \%$. However, behaviors in natural water are very different from one micropollutant to another. For example, for diclofenac and mecoprop, natural organic matter caused a reduction of $98 \%$ of adsorption capacities. The LangmuirFreundlich parameters (Table 7) in ground water correspond to the "EBC" and the initial concentration $\mathrm{C}_{0}(\mathrm{mg} \mathrm{DOC} / \mathrm{L})$ is the concentration of organic matter which was in competition with each pollutants. These values of $\mathrm{C}_{0}$ are very similar and close to $20 \mathrm{mg} \mathrm{DOC} / \mathrm{L}$.

In order to appreciate the impact of $\mathrm{EBC}$ on the adsorption of target molecules, a simulation of NOM adsorption was performed as shown in Figure 4. For a value of $1 \mathrm{mgDOC/L}$, we are already in the plateau of the curves. As a reminder, the initial concentration of COD in groundwater is about $2.9 \mathrm{mg}$ DOC/L. Whatever the micropollutant, the values of adsorption capacity at the equilibrium are of the same order of magnitude excepted in the presence of Mecoprop at lower concentration in solution. However, comparing the adsorption capacities $\left(\mathrm{q}_{\mathrm{m}}\right)$ in Table 8, the adsorption of micropollutants is better than the adsorption of NOM in natural groundwater. 

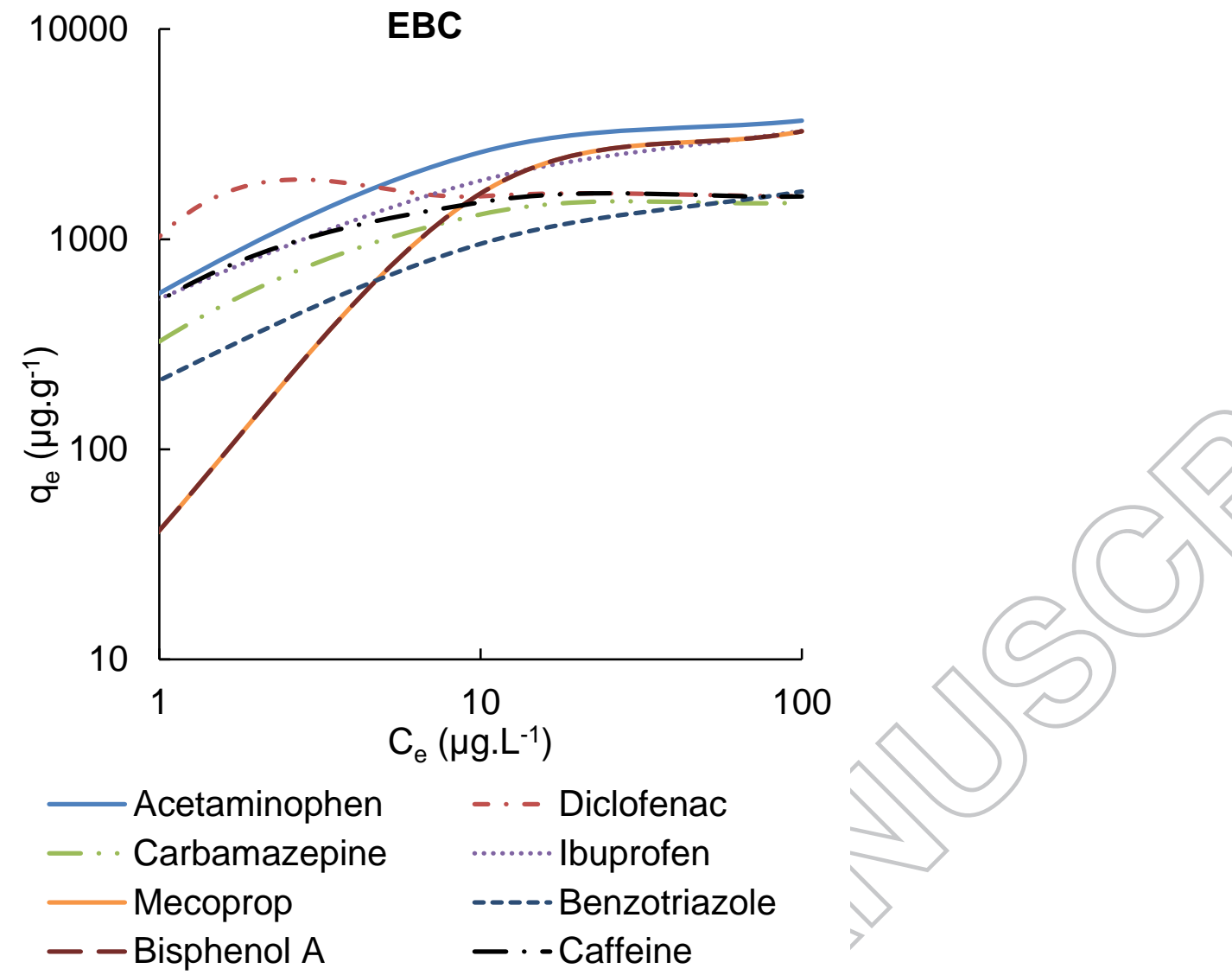

Figure 4 Simulation of the adsorption of EBC (Equivalent Background Compound) ( $\square \mathrm{g}$ DOC/L) onto ACFC in the presence of micropollutants 


\section{Parameters}

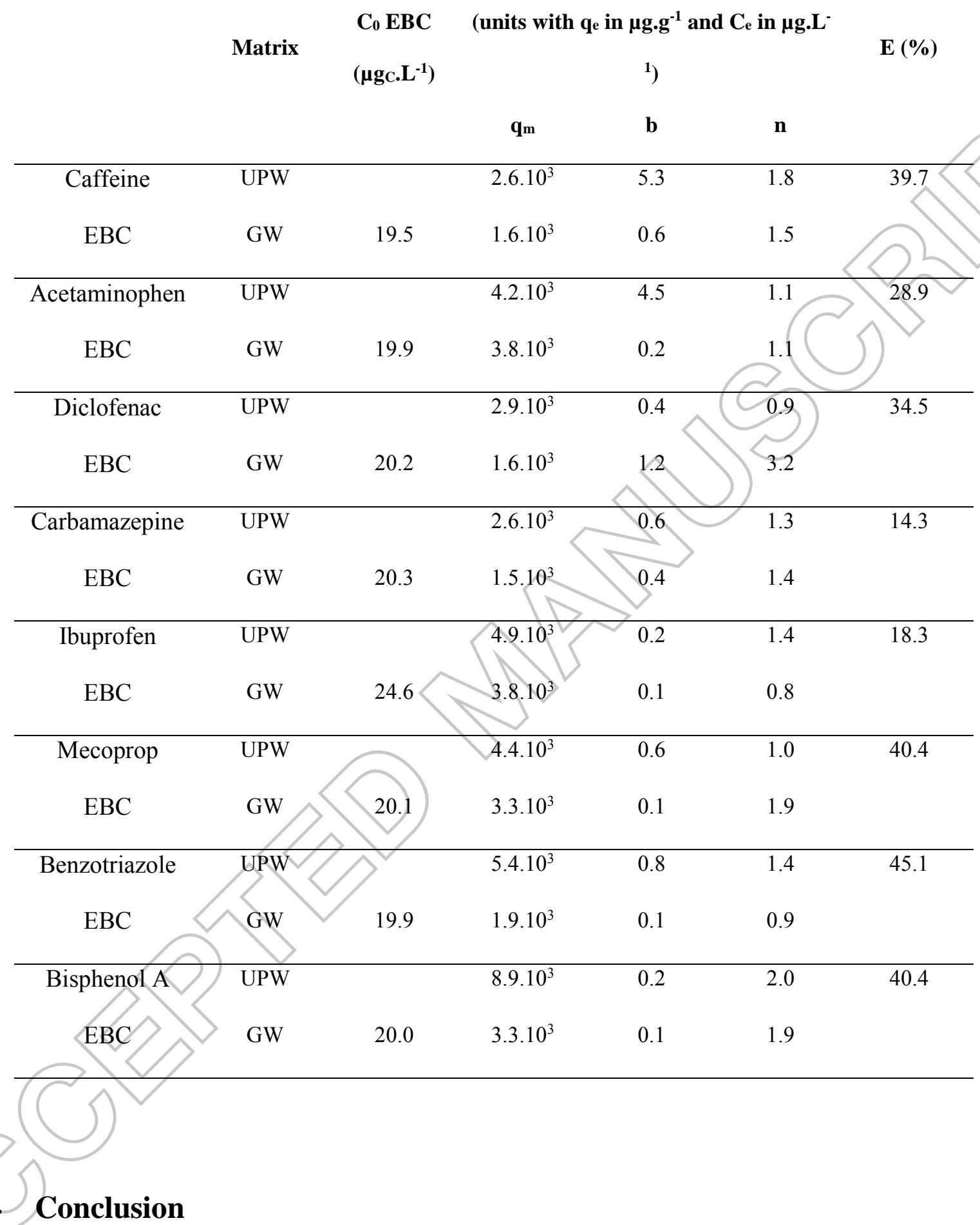

The adsorption of eight micropollutants onto activated carbon fiber cloth (ACFC) was studied in batch reactors (kinetics and isotherm equilibria) within three aqueous matrices: ultrapure, ground waters and diluted (1/2) groundwater. Experimental data of adsorption were generated for 8 pharmaceutical residues in mixture at low concentrations (between $100 \mathrm{ng} / \mathrm{L}$ to $10 \square \mathrm{g} / \mathrm{L}$ ). We have to note the 
adsorption of such pharmaceutical residues. The impacts of NOM were enlightened. Indeed, in batch reactors, large detrimental influences of NOM were shown on adsorption capacities. The reduction higher than $75 \%$ in natural water, containing $2.9 \mathrm{mgDOC} . \mathrm{L}^{-1}$ approximatively, was found in comparison to ultrapure water). The kinetics were modeled with HSDM and IAST model. The mass transfer coefficients and the diffusion coefficients were determined. They are found respectively in the order of $\mathrm{K}_{\mathrm{f}}=10^{-2}$ and $10^{-9}<\mathrm{Ds}<10^{-10}$. The Biot numbers had shown that the limiting mechanisms (external transfer and/or inner diffusion in the pore) were highly dependent on the nature of the target compound and, most often, affected by the presence of NOM.

\section{Acknowledgements}

The authors gratefully acknowledge the French National Research Agency (ANR-11-ECOT-0005) for funding a general program of research on the micropollutant removal in drinking water.

\section{References}

[1]de Jesus Gaffney V, Almeida CMM, Rodrigues A, Ferreira E, Benoliel MJ, Cardoso VV Occurrence of pharmaceuticals in a water supply system and related human health risk assessment, Water Research. 2015;72:199-208. doi:http://dx.doi.org/10.1016/j.watres.2014.10.027

[2]Huerta-Fontela M, Galceran MT, Ventura F. Occurrence and removal of pharmaceuticals and hormones through drinking water treatment, Water Research. 2011;45:1432-1442. doi: http://dx.doi.org/10.1016/j.watres.2010.10.036.

[3] Johnson AC, Dumont E, Williams RJ, Oldenkamp R, Cisowska I, Sumpter JP Do Concentrations of Ethinylestradiol, Estradiol, and Diclofenac in European Rivers Exceed Proposed EU Environmental Quality Standards?, Environmental Science \& Technology. 2013;47:12297-12304. doi:10.1021/es4030035.

[4]Roig B, D'Aco V Distribution of Pharmaceutical Residues in the Environment, in: Pharmaceuticals in the Environment, The Royal Society of Chemistry, 2016: pp. 34-69.

[5]Loos R, Locoro G, Contini S, Occurrence of polar organic contaminants in the dissolved water phase of the Danube River and its major tributaries using SPE-LC-MS2 analysis, Water Research. 2010;44:2325-2335. doi:http://dx.doi.org/10.1016/j.watres.2009.12.035.

[6]Segura PA, MacLeod SI, Lemoine P, Sauvé S, Gagnon C, Quantification of carbamazepine and atrazine and screening of suspect organic contaminants in surface and drinking waters, Chemosphere. 84 (2011) 1085-1094. doi:http://dx.doi.org/10.1016/j.chemosphere.2011.04.056.

[7] Bazus L, Cimetiere N, Wolbert D, Randon G., Development of on-line solid-phase extractionliquid chromatography coupled with tandem mass spectrometry method to quantify pharmaceutical, 
glucuronide conjugates and metabolites in water. Journal of Chromatography \& Separation Techniques. 2016;7:337-341.

[8] Webb S, Ternes T, Gibert M, Olejniczak K, Indirect human exposure to pharmaceuticals via drinking water, Toxicology Letters. 2003;142:157-167. doi:http://dx.doi.org/10.1016/S03784274(03)00071-7.

[9] Cunningham VL, Binks SP, Olson MJ Human health risk assessment from the presence of human pharmaceuticals in the aquatic environment, Regulatory Toxicology and Pharmacology. 2009;53:3945. doi:http://dx.doi.org/10.1016/j.yrtph.2008.10.006.

[10] Paltiel O, Fedorova G, Tadmor G, Kleinstern G, Maor Y, Chefetz B Human Exposure to Wastewater-Derived Pharmaceuticals in Fresh Produce: A Randomized Controlled Trial Focusing on Carbamazepine, Environmental Science \& Technology. 2016;50:4476-4482. doi:10.1021/acs.est.5b06256.

[11] Altmann J, Rehfeld D, Träder K, Sperlich A, Jekel M Combination of granular activated carbon adsorption and deep-bed filtration as a single advanced wastewater treatment step for organic micropollutant and phosphorus removal, Water Research. 2016;92:131-139.

doi:http://dx.doi.org/10.1016/j.watres.2016.01.051.

[12] Meinel F, Zietzschmann F, Ruhl AS, Sperlich A, Jekel M The benefits of powdered activated carbon recirculation for micropollutant removal in advanced wastewater treatment, Water Research. 2016;91:97-103. doi:http://dx.doi.org/10.1016/j.watres.2016.01.009.

[13] Gil A, Taoufik N, Garcia A et al. Comparative removal of emerging contaminants from aqueous solution by adsorption on an activated carbon, Environ. Technol., 2019;40:3017-3030.

[14]de Almeida A, Alcione A, de Oliveira R, Giselle L et al., Performance of the fixed-bed of granular activated carbon for the removal of pesticides from water supply, Environ. Technol., 2019;40: 1977-

1987.

[15] Rigobello ES, Dantas ADB, Di Bernardo L, Vieira EM Removal of diclofenac by conventional drinking water treatment processes and granular activated carbon filtration, Chemosphere. 2013;92:184-191. doi:http://dx.doi.org/10.1016/j.chemosphere.2013.03.010.

[16] Sotelo JL, Ovejero G, Rodríguez A, Álvarez S, Galán J, García J Competitive adsorption studies of caffeine and diclofenac aqueous solutions by activated carbon, Chemical Engineering Journal. 2014;240:443-453. doi:http://dx.doi.org/10.1016/j.cej.2013.11.094.

[17] Cai N, Larese-Casanova P Sorption of carbamazepine by commercial graphene oxides: A comparative study with granular activated carbon and multiwalled carbon nanotubes, Journal of Colloid and Interface Science. 2014;426:152-161. doi:http://dx.doi.org/10.1016/j.jcis.2014.03.038.

[18] Brasquet C, Le Cloirec P Effects of Activated Carbon Cloth Surface on Organic Adsorption in Aqueous Solutions. Use of Statistical Methods To Describe Mechanisms, Langmuir. 1999;15:59065912. doi:10.1021/la9811160P.

[19] Faur C, Métivier-Pignon H, Le Cloirec P Multicomponent Adsorption of Pesticides onto Activated Carbon Fibers, Adsorption. 2005;11:479-490. doi:10.1007/s10450-005-5607-2.

[20] Ayranci E, Hoda N Adsorption kinetics and isotherms of pesticides onto activated carbon-cloth, Chemosphere. 2005;60:1600-1607. doi:http://dx.doi.org/10.1016/j.chemosphere.2005.02.040.

[21] Le Cloirec P, Brasquet C, Subrenat E, Adsorption onto Fibrous Activated Carbon: Applications to Water Treatment, Energy \& Fuels. 1997;11:331-336. doi:10.1021/ef9601430.

[22] Dąbrowski A, Podkościelny P, Hubicki Z, Barczak M Adsorption of phenolic compounds by activated carbon-a critical review, Chemosphere. 2005;58:1049-1070.

doi;http://dx.doi.org/10.1016/j.chemosphere.2004.09.067.

[23] Ayranci E, Duman O Adsorption of aromatic organic acids onto high area activated carbon cloth in relation to wastewater purification, Journal of Hazardous Materials. 2006,136:542-552. doi:http://dx.doi.org/10.1016/j.jhazmat.2005.12.029.

[24] Bayram E, Ayranci E Electrosorption based waste water treatment system using activated carbon cloth electrode: Electrosorption of benzoic acid from a flow-through electrolytic cell, Separation and Purification Technology. 2012,86:113-118. doi:http://dx.doi.org/10.1016/j.seppur.2011.10.032.

[25] Baudu M., Le Cloirec P., Martin G Modélisations d'isothermes d'adsorption sur charbon actif de composés aromatiques en solution aqueuse. Chemical Engineering Journal, 1989;41:81-89 
[26]Boulinguiez B, Le Cloirec P, Wolbert D Revisiting the determination of Langmuir parameters Application to Tetrahydrothiophene adsorption onto activated carbon, Langmuir. 24 2008;24:6420 6424.

[27] Foo KY, Hameed BH Insights into the modeling of adsorption isotherm systems, Chemical Engineering Journal. 2010;156:2-10. doi:http://dx.doi.org/10.1016/j.cej.2009.09.013.

[28] Fallou H, Cimetière N, Giraudet S, Wolbert D, Le Cloirec P Adsorption of pharmaceuticals onto activated carbon fiber cloths - Modeling and extrapolation of adsorption isotherms at very low concentrations, Journal of Environmental Management. 2016;166:544-555. doi:http://dx.doi.org/10.1016/j.jenvman.2015.10.056.

[29] Zietzschmann F, Stützer C, Jekel M Granular activated carbon adsorption of organic micropollutants in drinking water and treated wastewater - Aligning breakthrough curves and capacities, Water Research. 2016;92:180-187. doi:http://dx.doi.org/10.1016/j.watres.2016.01.056.

[30] Meinel F, Ruhl AS, Sperlich A, Zietzschmann F, JekelM Pilot-Scale Investigation of Micropollutant Removal with Granular and Powdered Activated Carbon, Water, Air, \& Soil Pollution. 226 (2014) 1-10. doi:10.1007/s11270-014-2260-y.

[31] Kennedy AM, Summers RS Effect of DOM Size on Organic Micropollutant Adsorption by GAC, Environmental Science \& Technology. 2015;49:6617-6624. doi:10.1021/acs.est.5b00411.

[32] Worch E Adsorption Technology in Water Treatment, Fundamentals, Processes, and Modeling, De Gruyter, Berlin, Boston, 2012.

[33] Cimetiere N, Soutrel I, Lemasle M, Laplanche A, Crocq A Standard addition method for the determination of pharmaceutical residues in drinking water by SPE-LC-MS/MS., Environmental Technology. 33 (2013) 3031-3041.

[34] Rouquerol J, Avnir D, Everett DH, Fairbridge C, Haynes M, Pernicone N, Ramsay JDF, Sing KSW, Unger KK Guidelines for the Characterization of Porous Solids, in: F.R.-R.K.S.W.S. J. Rouquerol, K. K. Unger (Eds.), Studies in Surface Science and Catalysis, Elsevier, 1994: 1-9.

[35] Condon JB An Overview of Physisorption, in: Surface Area and Porosity Determinations by Physisorption, Elsevier Science, Amsterdam, 2006: 1-27.

[36] Boehm H, Some aspects of the surface chemistry of carbon blacks and other carbons, Carbon. 1994;32:759-769. doi:http://dx.doi.org/10.1016/0008-6223(94)90031-0.

[37]Lopez-Ramon MV, Stoeckli F, Moreno-Castilla C Carrasco-Marin F On the characterization of acidic and basic surface sites on carbons by various techniques, Carbon. 37 (1999) 1215-1221. doi:http://dx.doi.org/10.1016/S0008-6223(98)00317-0.

[38] Radke CJ, Prausnitz JM Adsorption of Organic Solutes from Dilute Aqueous Solution of Activated Carbon, Industrial \& Engineering Chemistry Fundamentals. 1972;11:445-451. doi:10.1021/i160044a003.

[39] Najm N, Snoeyink VL, Suidan MT, Lee CH, Richard Y Effect of particle size and background natural organics on the adsorption efficiency of PAC. Journal American Water Works Association. 1990;82:65-72.

[40] Shimabuku KK, Cho H, Townsend EB, Rosario-Ortiz FL, Summers RS, Modeling Nonequilibrium Adsorption of MIB and Sulfamethoxazole by Powdered Activated Carbon and the Role of Dissolved Organic Matter Competition, Environmental Science \& Technology. 2014:48:13735-13742. doi:10.1021/es503512v.

[41] Gicquel L, Wolbert D, Laplanche A Adsorption of Atrazine by Powdered Activated Carbon: Influence of Dissolved Organic and Mineral Matter of Natural Waters, Environmental Technology. 1997;18: 467-478. doi:10.1080/09593330.1997.9618521.

[42] Baup S, Jaffre C, Wolbert D, Laplanche A Adsorption of Pesticides onto Granular Activated Carbon: Determination of Surface Diffusivities Using Simple Batch Experiments, Adsorption. 2000;6:219-228. doi:10.1023/a:1008937210953.

[43] Baup S, Wolbert D, Laplanche A Importance of Surface Diffusivities in Pesticide Adsorption Kinetics onto Granular Versus Powdered Activated Carbon: Experimental Determination and Modeling, Environmental Technology. 2002;23: 1107-1117. doi:10.1080/09593332308618339.

[44] Dudamel WJ, Wolbert D, de Cazeaudumec YR Modeling of the adsorption kinetics of pesticides in aqueous phase on activated carbon considering temperature effects, Interciencia. 35 (2010) 255262. 
[45] Traegner UK, Suidan MT Evaluation of surface and film diffusion coefficients for carbon adsorption, Water Research. 1989;23: 267-273. doi:http://dx.doi.org/10.1016/0043-1354(89)90091-2. [46] Matthews AP, Weber WJ Effects of external mass transfer and intraparticle diffusion on adsorption rates in slurry reactors, AIChE Symposium Series. 1977;73:91-98.

[47] Li Q, , Snoeyink VL,. Mariñas BJ et al. Pore blockage effect of NOM on atrazine adsorption kinetics of PAC: the roles of PAC pore size distribution and NOM molecular weight. J. Environ. Engn. 2003; 37: 4863-4872. https://doi.org/10.1016/j.watres.2003.08.018.

[48] To PC, Mariñas BJ, Snoeyink VL, et al. Effect of Pore-Blocking Background Compounds on the Kinetics of Trace Organic Contaminant Desorption from Activated Carbon, Environ. Sci. Technol. 2008;42: 4825-4830.

[49] Bunmahotama W, Hung, WN, Lin TF Prediction of the adsorption capacities for four typical organicpollutants on activated carbons in natural waters, Water Res., 2017; 111: 28-40. 